\title{
NILAI, NORMA DAN KEYAKINAN REMAJA DALAM MENYEBARKAN INFORMASI SEHARI-HARI DI MEDIA SOSIAL
}

\author{
Margareta Aulia Rahman \\ Dosen Program Studi Ilmu Perpustakaan Departemen Ilmu Perpustakaan dan Informasi, Fakultas \\ Ilmu Pengetahuan Budaya, Universitas Indonesia
}

\begin{abstract}
ABSTRAK
Penelitian ini membahas nilai-nilai, norma dan kepercayaan remaja dalam menyebarkan informasi di media sosial. Proses penyebaran informasi tidak hanya karena teknologi yang memungkinkan informasi untuk disebarluaskan tetapi kehadiran budaya di media sosial untuk mendistribusikan kembali informasi yang diperoleh. Budaya ini kemudian berkembang menjadi kebiasaan digital bagi pengguna media sosial. Jadi tujuan dari penelitian ini menggambarkan nilai-nilai, norma dan kepercayaan remaja dalam menyebarkan informasi di media sosial, yang dipahami dan mendasari remaja dalam menyebarkan informasi. Pendekatan penelitian yang digunakan adalah kualitatif dengan metode fenomenologis. Metode pengumpulan data menggunakan wawancara dan observasi. Hasil penelitian ini nilai, norma dan kepercayaan adalah filter untuk informasi yang akan disebarkan oleh remaja. Nilai saling menghargai itu membuat remaja tidak serta merta menyebarkan informasi di media sosial. Norma yang disampaikan oleh orang tua dan guru di sekolah dan pemahaman mereka tentang kepercayaan memiliki pengaruh besar pada keputusan remaja untuk menyebarkan informasi.
\end{abstract}

Kata kunci: nilai, norma dan kepercayaan; penyebaran informasi, penyebaran informasi remaja, media sosial

\begin{abstract}
This study discusses the values, norms and beliefs of teenagers in disseminating information in social media. The process of disseminating information is not only due to technology that allows information to be disseminated but the presence of culture in social media to redistribute the information obtained. This culture then evolved into a digital habit for social media users. So the purpose of this study illustrates the values, norms and beliefs of teenagers in disseminating information in social media, which understood and underlies adolescents in disseminating information. The research approach used is qualitative with phenomenological method. Data collection methods used interview and observation. The results of this study values, norms and beliefs is a filter for information to be disseminated by adolescents. The value of mutual respect that makes teenagers do not necessarily disseminate information in social media. Norms delivered by parents and teachers at school and their understanding of beliefs have a major influence on teenagers' decisions to spread information.
\end{abstract}

Keywords: values, norms and beliefs; information dissemination, dissemination of teenagers information, social media

\section{PENDAHULUAN}

Proses penyebaran informasi tersebut tentunya dipengaruhi oleh nilai, norma dan keyakinan seseorang. Proses penyebaran informasi tidak hanya terjadi karena teknologi yang 
memungkinkan informasi untuk disebarkan tetapi juga karena budaya yang ada di media sosial untuk menyebarkan kembali informasi yang diperoleh. Budaya ini kemudian berkembang menjadi kebiasaan digital bagi pengguna media sosial. Praktiknya ada nilai, norma dan keyakinan yang mendasari pengguna sosial media menyebarkan informasi. Laksmi (2016) mengatakan bahwa masyarakat Indonesia umumnya memiliki sifat yang tertutup. Seorang individu hanya akan memberikan informasi kepada orang-orang terdekatnya, apalagi jika menyangkut kehidupan pribadi. Seseorang yang mengungkapkan rahasia kehidupan pribadinya justru akan dianggap tidak sopan dan membongkar aib. Kebiasaan menyimpan informasi secara ekslusif dan kebiasaan berkomunikasi hanya untuk dua orang saja terkikis habis dengan munculnya media sosial. Individu tidak lagi dapat menyembunyikan rahasianya, sehingga berdampak pada munculnya pencurian hak kepemilikan rahasia, plagiarisme tidak dapat dihindari, dan masih banyak kecurangan lain. Hal ini disebabkan karena informasi di media sosial disebarkan dengan cepat bahkan tanpa terbatas ruang dan waktu, serta dapat dengan mudah dilihat oleh khalayak. Media sosial dapat menyebarkan informasi sebuah peristiwa yang terjadi di lapangan bahkan baru terjadi beberapa detik.

Namun demikian penyebaran informasi di media sosial dapat juga sangat efektif untuk memberikan pemahaman dan pengetahuan kepada khalayak. Sebagai contoh penyebaran informasi banyak dilakukan pada bidang kesehatan untuk membantu mempercapat keberhasilan pencapaian tujuan pembangunan kesehatan. Penelitian Laksono pada tahun 2011 dengan judul Analisis Potensi Penyebaran Informasi Kesehatan Melalui Jejaring Sosial (Studi Kasus pada "Forum Jejaring Peduli AIDS") dapat diambil kesimpulan bahwa media jejaring social melalui internet sangat efektif sebagai sebuah media penyebaran informasi yang melampaui kendala geografis maupun administrative wilayah. Media Jejaring Sosial juga efektif untuk penyebaran informasi dengan sasaran remaja dan usia produktif.

Kekuatan ini memberikan perubahan pada perilaku masyarakat, salah satunya remaja. Hal ini terjadi karena bagi remaja keberadaan telpon genggam menjadi kebutuhan yang tidak lagi sekunder tetapi sudah masuk kedalam kebutuhan primer. Kebutuhan yang seolah-olah menjadi syarat keberadaan (eksistensi) dan menjadi pintu masuk alias portal menuju konektifitas bergaul pada era saat ini (Nasrullah: 2015). Fenomena tersebut menunjukkan bahwa teknologi dan perangkat media yang ada telah benar-benar tidak dapat dipisahkan dari kehidupan seseorang. Teknologi menjadikan seseorang untuk menjadi bagian dari masyarakat informasi yang memiliki jejering (network society) tanpa batasan demografis, budaya, sosial 
dan sebagainya. Seperti yang diungkapkan oleh Mary Cross, Profesor dari Fairleigh Dickinson University mengatakan bahwa "We are already experiancing the cultural effects of the digital revolution that is underway",(Cross, 2011: 23). Dimana kita sedang mengalami efek budaya dari revolusi digital yang sedang berlangsung. Untuk itu penelitian mengenai nilai, norma dan keyakinan remaja dalam menyebaran informasidi media sosial baik melalui facebook, twetter, instagram, youtube, maupun media sosial lainnya menarik untuk dilakukan.

Tidak hanya itu, budaya informasi di dalam masyarakat dibangun melalui kegiatan berbagi infomasi. Dengan berbagi informasi, setiap individu dapat mendapatkan pengetahuan baru, dapat saling mengoreksi lalu menggabungkan pengetahuan bersama dan akhirnya menciptakan pengetahuan. Hal ini terjadi karena perkembangan teknologi informasi membuat informasi dapat dengan mudah diciptakan, disebarkan dan akses termasuk oleh remaja. Friedman (2007) mengatakan bahwa world is flat bahwa dunia semakin rata dan setiap orang dapat mengakses apapun dari sumber manapun. Media sosial memberikan keleluasaan bagi khalayak, termasuk didalamnya remaja, untuk ikut menyebarkan informasi atau peristiwa yang terjadi disekitar mereka. Pada penelitian ini yang dimaksud media sosial adalah situs jejaring sosial yang digunakan untuk mempublikasikan konten, seperti profil, aktivitas, pendapat sebagai bagian dari interaksi di dunia maya. Berdasarkan fenomena yang dipaparkan diatas maka tujuan dari penelitian inimengidentifikasi nilai, norma dan keyakinan yang dipahami yang mendasari remaja dalam melakukan penyebaran informasi sebagai bagian dari budaya informasi. Budaya informasi merupakan cara hidup masyarakat yang menjadikan informasi sebagai pusat kegiatan dalam kehidupan masyarakat sehari-hari.

\section{METODE PENELITIAN}

Penelitian ini menggunakan pendekatan kualitatif.Pendekatan kualitatif adalah proses penelitian yang mendasarkan perolehan data berdasarkan konteks berlangsungnya rangkaian peristiwa, yang dideskripsikan secara rinci dengan sudut pandang para informan terkait peristiwa-peristiwa tersebut, dan dijelaskan dengan cara berpikir induktif (Gorman, 2005: 3). Metode yang akan digunakan dalam penelitian ini adalah fenomenologi. Fenomenologi memahami budaya lewat pandangan pemilik budaya atau pelakunya. Yang ditekankan adalah aspek subjek dari perilaku orang (Endraswara, 2012:44). Peneliti fenomenologi masuk ke dunia konseptual para subjek yang ditelitinya sedemikian rupa sehingga mereka mengerti apa dan bagaimana suatu pengertian yang mereka kembangkan di sekitar peristiwa dalam 
kehidupannya sehari-hari. Pemahaman dan pengertian yang mendalam dari subjek yang mengalami dan mendasari setiap keputusannya untuk melakukan penyebaran informasi di media sosial.

Jumlah informan penelitian sebanyak 6 (enam) orang yang diseleksi berdasarkan metode purposive sampling, dengan kriteria sebagai berikut: informan merupakan siswa Sekolah Menengah Atas (SMA/SMK/MAN) yang berusia 16-18 tahun, informan aktif melakukan penyebaran informasi di media sosial, dan tinggal di wilayah Jakarta, Bogor, Jakarta dan Bekasi (Jabodetabek).

Metode pengumpulan data akan menggunakan observasi dan wawancara. Observasi yang dilakukan adalah mengamati perilaku informan dalam mengakses dan menyebarkan informasi di media sosial, termasuk gajet yang dipakai, lingkungan sekitar informan, serta mengamati kegiatan dan hobi dari masing-masing informan. Pada proses wawancara pertanyaan yang diajukan adalah pertanyaan mengenai proses penyebaran informasi, akses informasi, termasuk nilai, norma dan keyakinan dalam menyebarkan informasi. Bagaimana pengalaman dan pemahaman informan digali kemudian dimaknai dan pada akhirnya ditarik menjadi sebuah kesimpulan penelitian.

\section{HASIL DAN PEMBAHASAN}

Budaya informasi merupakan cara hidup masyarakat yang menjadikan informasi sebagai pusat kegiatan dalam kehidupan masyarakat sehari-hari (Laksmi, 2016). Pada remaja yang tinggal di wilayah urban, segala aktivitas kesehariannya telah menggunakan informasi yang ada di media sosial sebagai pusat dari kegiatan. Mereka dikenal dengan sebutan net generation atau digital nativesdimana remaja tumbuh bersamaan dengan berkembangnya internet dan dapat dengan mudah beradaptasi memanfaatkan internet. Seiring dengan perkembangan internet, media sosial juga semakin marak untuk digunakan oleh remaja. Hal ini sesuai dengan pengertian dari media sosial, dimana media sosial didefinisikan sebagai medium di internet yang memungkinkan pengguna merepresentasikan dirinya maupun berinteraksi, bekerja sama, berbagi, berkomunikasi dengan pengguna lain dan membentuk ikatan sosial (Narullah, 2015: 11). Untuk membahas nilai, norma dan keyakinan remaja dalam menyebarkan informasi maka perlu diketahui juga bagaimana akses terhadap informasi dan jenis dari informasi yang disebarkan oleh remaja.

\section{Akses terhadap informasi}


Media sosial dapat menyebarkan informasi sebuah peristiwa yang terjadi di lapangan bahkan baru terjadi beberapa detik. Kekuatan ini memberikan perubahan pada perilaku masyarakat, salah satunya remaja. Kini, bagi remaja keberadaan telpon genggam menjadi kebutuhan yang tidak lagi sekunder tetapi sudah masuk kedalam kebutuhan primer. Hal ini terlihat dari kutipan wawancara dengan para informan ketika ditanyakan frekuensi mengakses media sosial menggunakan gadget mereka.

"Sering”(Lidya)

"Setiap waktu kayanya. Saya sering buka internet apalagi kalau lagi bosen hehehe...(Arfa)"

"Di rumah, sekolah, sambil nongkrong sama temen-temen"(Alif)

"Tak terhingga saking seringnya”, "Dimana mana saja kadang sampai kamar mandi juga suka internetan" (Balqis)

"Dimana aja, hp nggak pernah lepas dari saya" (Salsabila)

Masyarakat informasi muncul dalam masyarakat urban dengan ciri penggunaan informasi pada setiap aktifitas. Hal ini terlihat dari masyarakatnya, khususnya remaja yang tidak dapat lepas dari gadget. Kemudahan dalam mengakses informasi diperkotaan adalah salah satu faktor pendorong remaja dapat mengakses media sosial dimana dan kapanpun mereka inginkan. Infrastruktur teknologi informasi di daerah perkotaan sudah sedemikian memungkinkan remaja tidak akan terputus informasi. Hal ini terlihat dari kutipan wawancara dengan semua informan dimana keseluruhan informan tidak dapat jauh dari telpon genggam mereka. Bahkan dikatakan dimanapun dan kapanpun Hp tidak pernah terlepas dari informan.

Adapun informasi yang disebarkan oleh informan adalah berkaitan dengan hobi dan eksistensi (berkaitan dengan aktivitas di sekolah dan dalam pergaulan). Hal ini terlihat dari kutipan wawancara dengan informan saat ditanya mengenai jenis informasi yang disebarkan, sebagai berikut:

"hobi saya KIR...OSIS"

"Baca novel"

"mendengarkan musik"

"olahraga dan main musik"

"Informasi tentang sepakbola, kadang suka nyari info dari band-band legend sepanjang masa contohnya kaya the beatles, queen, led zeppelin gitu-gitu” (Arfan)

"Informasi tentang artis idola, informasi yang belum diketahui atau memastikan sebuah berita hoax atau benar. Tapi saya lebih sering cari informasi tentang artis idola. Kaya One Direction..saya suka banget sama 1D itu, lagunya bagus-bagus terus juga orangnya ganteng-ganteng” (Bilqis)

"Artis sih. Iya kadang suka buka yang tentang gossip artis, habisnya seru” (Salsabila) 
Situs jejaring sosial biasanya menyediakan pengguna dengan ruang profil, fasilitas untuk mengunggah konten (misalnya foto, musik), pesan dalam berbagai bentuk dan kemampuan untuk membuatnya koneksi ke orang lain. Selain itu situs jaringan sosial sebagian besar juga memberi kesempatan untuk komunikasi, pembentukan kelompok, hosting konten dan lain sebaginya. Berdasarkan uraian tersebut, inforan membutuhkan informasi untuk mendapatkan jawaban untuk kepentingan tugas sekolah, hobi dan kesenangan. Hal ini sesuai dengan apa yang disampaikan oleh Laksmi (2016) bahwa substansi berbagi informasi melalui media sosial yang dilakukan oleh masyarakat umumnya tidak dilakukan untuk memperoleh informasi yang penting. Umumnya informasi yang dikirim atau diterima mengenai hal-hal yang ringan, seperti bertanya kabar masing-masing, mengirim ucapan selamat, mengirim gambar makanan sebuah restoran, atau sekedar mengirim meme grauan. Fenomena yang terlihat adalah banyak netizen yang memanfaatkannya untuk berekspresi dan memamerkan diri, membuat ststus pada timeline dengan harapan bahwa seseorang mengetahui apa yang sedang saat ini sedang dirasakan oleh dirinya. Hal ini juga terlihat pada informan penelitian dimana hobi dan kesenangan seperti mencari musik, melihat kabar artis atau mengetahui informasi terbaru mengenai artis idola adalah hal yang dilakukan di media sosial.

Padahal dalam melakukan identifikasi kebutuhan informasi, terdapat tiga faktor yang harus dipenuhi, yaitu (Sankarto, 2008: 10); a) lengkap, artinya semua informasi yang diharapkan pengguna didapatkan oleh pihak yang melakukan identifikasi b) detail, adalah informasi yang terkumpul rinci sampai ke hal-hal yang kecil c) benar, yaitu semua data yang diperoleh harus benar, bukan berarti menurut identifikator tetapi benar dan sesuai dengan apa yang dimaksud. Keberadaan media sosial tidak lagi sesuai dengan kebutuhan informasi namun lebih pada adanya efek budaya. Dimana kegiatan mencari dan mendapatkan informasi dilakukan bukan karena ada kebutuhan akan informasi namun kebutuhan akan terhubung dengan dunia maya menjadi budaya anak muda usia remaja. Informan masih sulit mengidentifikasi kebutuhan informasi mereka, yang mereka lakukan hanya pada pencarian informasi yang masih bersifat ringan. Namun, secara keseluruhan jenis informasi yang mereka butuhkan adalah informasi yang sesuai dengan hobi, kesenangan dan kegiatan mereka di sekolah. Hal tersebut yang mendorong mereka untuk mengakses media sosial.

Ketergantungan terhadap informasi menunjukkan remaja di daerah urban memiliki ciri masyarakat informasi, dimana setiap kegiatan yang dilakukan memfokuskan pada pencarian informasi. Pencarian informasi timbul karena adanya kebutuhan akan pemenuhan 
informasi. Pada dasarnya seseorang membutuhkan informasi berdasarkan fungsi atau tujuannya. Fungsi dan tujuan informasi menurut Nicholas (2008: 48), meliputi; 1) pencarian fakta dengan fungsi, memberikan jawaban atas pertanyaan yang spesifik, 2) untuk agar tetap up-to date, 3) penyelidikan dari suatu bidang baru yang mendalam (fungsi penelitian), 4) untuk mendapatkan pemahaman latar belakang masalah atau topik (fungsi pengarahan), 5) untuk menyediakan ide atau stimulus (fungsi stimulus). Bagi informan, tujuan pencarian informasi adalah agar mereka tetap up-to date. Berikut merupakan contoh berita dari laman facebook yang membuat informan lebih up-to date karena mengetahuinya.

Saat suatu berita menyebar di media sosial maka pembicaraan dalam pergaulan membahas mengenai berita tersebut. Informanyang mengetahui berita ini akan merasa memiliki bahan pembicaraan dan eksistensinya diakui. Sebaliknya, informan yang tidak atau belum tahu tentang berita ini akan memiliki keinginan untuk mengetahui dan membaca berita ini agar menjadi up to date. Kebutuhan akan informasi muncul ketika mereka mendapatkan triger (pemicu) adanya keingintahuan dan agar tetap uptodate membuat remaja menjadikan akses terhadap media sosial tidak dapat dipungkiri.

Akses terhadap informasi menjadi kebutuhan yang seolah-olah menjadi syarat keberadaan (eksistensi) dan menjadi pintu masuk alias portal menuju konektifitas bergaul pada era saat ini (Nasrullah: 2015).Informan merasa dengan menyebarkan informasi pada akun media sosial yang mereka miliki, akan membuat mereka dekat dan diterima dengan komunitasnya (peer group).

Seperti yang data yang disebutkan oleh Lembaga We are Social, dalam penelitian mereka tentang perilaku internet, akses terhadap internet hingga akun media sosial dari seluruh dunia. Data di Indonesia pada Januari 2014 menunjukkan sekitar 15\% atau 38 juta orang mengakses internet, dan ada sekitar 62 juta orang yang terdaftar serta memiliki akun dimedia sosial facebook. Faktanya remaja di Indonesia, memiliki lebih dari 3 akun media sosial. Setiap informan memiliki setidaknya 3 akun media sosial yang digunakan untuk menyebarkan informasi.

"Oh... Line sama E-mail"

"WhatsApp sama brainly"

"Instagram" "Facebooknya"

"Instagram, Facebook, sama Twitter"

"Instagram dan Path soalnya paling asik dibandingin yang lain” 
Adanya media sosial berupa situs jejaring sosial seperti Facebook, Instagram, dsb memberikan kemudahan bagi remaja untuk menyebarkan informasi seperti profil, saling melihat aktivitas, bahkan memberikan komentar dan pendapat pada sebuah informasi yang ada baik berupa artikel berita atau aktivitas orang lain. Fasilitas di Facebook seperti "wall" dapat dimanfaatkan pengguna untuk mengungkapkan apa yang sedang disaksikan atau dialami, bercerita tentang keadaan disekitar dirinya, hingga bagaimana tanggapan terhadap situasi, misalnya politik pada saat ini (Nasrullah, 2014b).

\section{Penyebaran informasi}

Penyebaran (share/sharing) merupakan salah satu karakter dari media sosial (Nasrullah, 2015). Medium ini tidak hanya menghasilkan konten yang dibangun dan dikonsumsi oleh penggunanya, tetapi juga didistribusikan sekaligus dikembangkan oleh penggunanya (Benker, 2012; Cross, 2011).

"Saya biasanya sih karena diri sendiri aja. Enggak pernah orang tua atau temen-temen saya suruh saya share informasi... Tapi kalau informasi lain ya sesuai sama keinginan saya aja"...(Alif)

"Jarang banget. Saya lebih suka buat baca atau ngeliat informasi doang sih daripada share tapi kalau informasi itu penting banget dan diketahui sumbernya gitu saya akan ngesahre.” (Balqis)

"Keinginan sendiri sih, nggak pernah dipengaruhi sama sekali kalau share informasi" (Salsabila)

Hal tersebut seperti yang disebutkan oleh Griffiths and Brophy (2005) dan Cmor and Lippold dalam Rubin (2016: 382) bahwa remaja

1. menggunakan web (intenet/ media sosial) untuk segala aktifitas mereka;

2. mereka menggunakan intenet bahkan berjam-jam atau mungkin hanya juga sebentar saja;

3. keterampilan pencarian bervariasi dan remaja akan sering menilai diri mereka lebih terampil daripada mereka sebenarnya;

4. remaja akan memberikan komentar pada informasi apapun yang mereka baca Pada dasarnya penyebaran terdiri dari dua jenis, pertama melalui konten. Dimedia sosial, konten tidak hanya diproduksi oleh khalayak pengguna, tetapi juga didistribusikan secara manual oleh pengguna lain. Tentu secara otomatis program yang ada di tiap-tiap 
platform media sosial juga menyebarkan setiap konten yang telah terpublikasi dalam jaringan tersebut. Uniknya, konten tidak hanya terbatas pada apa yang telah terunggah. Konten di media sosial memungkinkan untuk berkembang dengan tambahan data, revisi informasi, komentar, sampai pada opini yang menyetujui atau tidak (Nasrullah, 2015). Hal ini juga dirasakan oleh informan dalam menyebarkan informasi dapat memberikan pendapat, sebagai tema diskusi dalam pembicaraan (chat), atau memberikan pandangan tertentu (up date status). Jenis penyebaran informasi yang kedua melalui perangkat, dimana teknologi menyediakan fasilitas untuk memperluas jangkauan konten, misalnya tombol "share" di Youtube yang berfungsi untuk menyebarkan konten video, baik ke platform media lainnya maupun pada media internet lainnya. Tombol ini juga berfungsi jika pengguna berkunjung ke situs tertentu dapat membagikan informasi yang ada ke media sosial. Medium ini tidak hanya menghasilkan konten yang dibangun dan dikonsumsi oleh penggunanya, tetapi juga didistribusikan sekaligus dikembangkan oleh penggunanya (Benker, 2012; Cross, 2011). Informan memiliki kekuasaan penuh untuk dapat Seperti juga yang terlihat pada kutipan wawancara berikut ini:

"Biasanya chat...." "Bikin status....." "Komen juga...."

"Paling buka instagram soalnya ya rame aja liat foto videosama foto orang-orang"

Gedget yang dimiliki oleh informan ini yang memudahkan baginya untuk menyebarkan informasi apasaja pada khalayak. Pada usia(16-18) tahun orang tua sudah memberikan informan masing-masing gadget untuk berkomunikasi. Kelemahan dalam melakukan penyebaran informasi oadalah kadang informan tidak memahami mana informasi yang benar. Hal ini dikarenakan, pada masa remaja ini cenderung mengalami keadaan emosi yang labil, sehingga dapat menyebabkan remaja sulit mendapatkan informasi yang dibutuhkan dengan tepat. Secara psikologis, remaja pada tingkatan siswa sekolah menengah sedang terjadinya ketidakstabilan karena besarnya kebutuhan akan informasi yang menjadi suatu masalah tersendiri (Agustriani, 2001). Disinilah keyakinan yang dipengaruhi oleh orang terdekat sangat berperan.

Terlihat dampak lain dari penggunaan media sosial adalah munculnya budaya berbagi yang berlebihandan pengungkapan diri (self disclosure) di dunia maya (Nasrullah, 2015). Budaya ini muncul karena hadirnya media sosial yang memungkinkan secara perangkat siapa pun dapat mengunggah apa saja. Cross (2011:25) dalam Nasrullah (2015) menyebutkan data tahun 2011 dalam satu musim saja terdapat sekitar 159 juta publikasi jurnal pribadi online 
atau blog atau setara dengan lebih dari 68 ribu publikasi setiap harinya. Pengungkapan tersebut yang menjadi sebuah budaya yang pada akhirnya memberikan pengaburan terhadap batas-batas antara ruang pribadi dan ruang publik. Sebuah status, misalnya di dinding Facebook bisa saja bercerita tentang kondisi yang di alami oleh sipemilik akun, tetapilayaknya komunikasi dua arah- kepada siapa status itu disampaikan, pun tidak dapat dijelaskan. Sebab, siapa pun dapat membaca status tersebut dan siapa pun juga walau tidak dalam jaringan pertemanan si pemilik akun dapat mengomentarinya. Hal ini juga yang dirasakan dan dilakukan oleh informan. Dimana kegiatan yang dilakukan membuat status, melihat, mengomentari dan menonton video di media sosial. Hal tersebut merupakan wujud dari budaya informasi.

Selain itu, alasan penyebaran informasi (Nasrullah: 2015) oleh informan diantaranya: (1) upaya membagi informasi yang dianggap penting kepada anggota komunitas (media) sosial lainya. Hal ini terlihat dari kutipan wawancara berikut:

"Iya kalau dapet dari guru dan sifatnya sangat penting, dan beberapa hari yang lalu pernah share berita anak-anak yang ikutan gangster yang ada di daerah rumah saya ini".

Informan memiliki komunitas di sekolah dan teman bermain diluar sekolah. Informasi yang mereka miliki ummnya akan disebarkan kepada anggota komunitas mereka jika dianggap penting; (2) Menunjukkan posisi atau keberpihakan khalayak terhadap sebuah isu atau informasi yang disebarkan. Informan memiliki keinginan untuk menyebarkan informasi yang mereka anggap penting agar oarang lain juga ikut berpihak dengan pendapatnya, meskipun informasi yang disebarkan hanya sebatas informasi yang sesuai dengan hobi mereka; (3) Konten yang disebarkan merupakan sarana untuk menambah informasi atau data baru lainnya sehingga konten menjadi semakin lengkap (crowdsourcing). Informan tidak memiliki minat yang tinggi untuk menambahkan informasi yang ada. Remaja berminat untuk membaca berita yang ada di media sosial dan memberikan komentar tanpa memproduksi atau menambahkan informasi pada sumber yang dibaca.

\section{Nilai, Norma dan Keyakinan dalam menyebarkan informasi}

Sebelum membicarakan nilai, norma dan keyakinan maka kita harus mendefinisikan kata budaya dan kebudayaan. Karena nilai, norma dan keyakinan merupakan salah satu dari aspek kebudayaan. Kata kebudayaan berasal dari terjemahan kata kultur. Kata kultur dalam bahasa Latin cultura berarti memelihara, mengolah, dan mengerjakan. Dalan kaitan ini 
cakupan kebudayaan menjadi sangat luas, seluas hidup manusia. Makna kebudayaan itu sendiri menurut Kroeber dan Kluckhohn (dalam Alisjahbana, 1986), dalam Endraswara (2012) definisi kebudayaan dapat digolongkan menjadi 7 (tujuh) hal: pertama, kebudyaaan sebagai keseluruhan hidup manusia yang kompleks, meliputi huku, seni, moral, adat istiadat, dan segaa kecakapan lainnya, yang diperoleh manusia sebagai anggota masyarakat. Kedua, menekankan pada sejarah kebudayaan, yang memandang kebudayaan sebagai warisan tradisi. Ketiga, menekankan kebudayaan yang bersifat normatif, yaitu kebudayaan dianggap sebagai cara atau aturan hidup manusia seperti cita-cita, nilai dan tingkah laku. Keempat, pendekatan kebudayaan dari aspek psikologis, kebudayaan sebagai langkah penyesuaian diri manusia kepada lingkungan sekitarnya. Kelima, kebudayaan dipandang sebagai struktur, yang membicarakan pola-pola dan organisasi kebudayaan serta fungsinya. Keenam, kebudayaan sebagai hasil perbuatan kecerdasaan. Kebudayaan adalah sesuatu yang membedakan atra manusia dan hewan, misalkan manusia pintar menggunakan simbol dalam komunikasi sedangkan hewan tidak. Ketujuh, definisi kebudayaan yang tidak lengkap dan kurang bersistem. Budaya bukan harga mati dan benda mati. Budaya adalah sesuatu yang dipelajari dan tidak semata-mata yang dilakukan orang. Hidup manusia akan memelihara, mengolah dan mengerjakan berbagai hal yang menghasilkan tindak budaya. Untuk itu meneliti budaya hendaknya menitik beratkan pada ruang dan waktu (Endraswara, 2012).

Berdasarkan definisi diatas, maka penelitian mengenai nilai, norma dan keyakinan menjadi salah salah satu kajian ilmu kebudayaan. Budaya pada dasarnya merupakan nilainilai yang muncul dari proses interaksi antar individu. Nilai yang diakui secara langsung maupun tidak seiring dengan waktu akan dilalui dalam interaksi tersebut. Bahkan, sebuah nilai berlangsung didalam alam bawah sadar individu dan diwariskan pada generasi berikutnya. Hatch (1997) menyebutkan bahwa nilai adalah prinsip sosial, tujuan, dan standar yang digunakan dalam suatu kebudayaan untuk meraih suatu nilai intrinsik. Nilainilai ini meliputi nilai kepatuhan, nilai kesetiaan, nilai penghargaan terhadap leluhur, nilai historis, dan sebagainya. Ciri adanya budaya adalah terdapat nilai, norma dan keyakinan yang dijadikan pedoman bagi masyarakat.

Nilai merupakan gagasan yang dipelajari/ ditanamkan sejak dini. Sedangkan norma pada intinya merupakan sesuatu tentang yang benar dan salah, dan keyakinan merupakan sesuatu yang menjadi dasar dalam bertindak atau berprilaku. Nilai di media sosial tidak hanya terjadi karena pembaruan perangkat, baik perangkat lunak (software) maupun keras (hardware) tetapi juga manusia sebagai entitas yang menggunakan atau dipengaruhi 
teknologi maupun cara berinteraksi dengan entitas lain di internet. Nilai, norma dan keyakinan yang pahami oleh remaja dalam meyebarkan informasi tergantung dari kedekatan informan kepada orang tua, kedekatan dengan peer dan pemahaman mereka terhadap keyakinan (agama). Hal ini sesuai dengan pandangan budaya, dimana budaya merupakan respon dari pemikiran manusia dan jawaban atau respons dari interaksi antarmanusia yang melibatkan pola-pola tertentu sebagai anggota kelompok dalam merespons lingkungan manusia itu berada.

Perkembangan media sosial sebagai media penyebaran informasi tidak lepas dari perkembangan Information Communication and Technology (ICT). Perspektif budaya memberikan sudut pandang yang berbeda pada perkembangan ICT. Dimana tidak dibahas cara merancang pangkalan data, cara membangun ICT, cara membangun jaringan teknologi atu yang lainya namun cenderung mempelajari dan memahami interaksi antara teknologi dan manusia. Perolle (1989) dalam Laksmi., et al (2010) menyatakan bahwa perspektif budaya memandang bahwa teknologi bukan sekedar kumpulan mesin tetapi merupakan suatu proses sosial yang memproduksi alat, perilaku sosial yang terlibat dalam penggunaan alat dan mendefinisikan makna alat dalam konteks budaya.

Mempelajari nilai yang dipedomani oleh remaja memberikan pemahaman akan alasan mengapa remaja berprilaku dengan cara tertentu, khususnya di media sosial. Laksmi., et al (2010) juga mengatakan bahwa memahami nilai juga dapat mengidentifikasi proses pengambilan keputusan dan juga dapat digunakan untuk menggali sumber permasalahan yang terjadi dam konteks antar budaya. Rokeach (Handbook,....2000: 37) dalam Laksmi., et al (2010) menyatakan bahwa nilai adalah kepercayaan yang dipilih baik secara individual maupun sekelompok masyarakat untuk berprilaku. Nilai juga bisa diartikan sebagai motif. Hubungan antara nilai-sikap-perilaku (value-attitudes- behavior) dapat dilihat dari hasil pengamatan. Perilaku adalah sesuatu yang dapat diamati dengan jelas, sedangkan nilai adaah sesuatu yang abstrak dan bersifat kognitif yang mempengaruhi sikap. Nilai individu bisa berubah-ubah karena dipengaruhi oleh usia, kedewasaan, pendidikan, pengalaman, dan terjadi dalam tingkatan yang berbeda-beda dan umumnya terjadi secara struktural.

"Laporkan pada pihak yang berwajib. Harusnya sih gitu ya, paling saya bilang ke Bapak saya dulu..." (Alif)

"Pokoknya jangan sampe mengganggu orang lain lah" (Alif)

"Enggak sama sekali soalnya saya nggak tau masalahnya apa. Kalau kata ibu saya, kalau nggak tau lebih baik diam aja" (Balqis) 
"Informasi yang sesuai norma, tidak mengejek agama, kelompok atau apapun, informasi yang benar, tidak meprofokasi, informasi yang penting dan menguntungkan orang lain"

"Iyaa dipikir dululah. Kalau nyinggung orang lain, ngapain juga disebar. Nggak baik kan"(Salsabila)

Dari semua informan terlihat adanya nilai saling menghormati dalam menyebarkan informasi. Informan telah mengerti bahwa ada nilai yang arus dijaga dalam berinteraksi dalam internet. Secara sederhana interaksi antar remaja terjadi di internet, namun pada kenyataannya internet tidak hanya sebuah perangkat teknologi tetapi juga terdapat didalamnya interaksi, komunikasi data, perangkat antarmuka, dan benak pikiran penggunanya sebagai entitas yang terhubung langsung.

Media dapat mempengaruhi, membangkitkan dan menciptakan pengatahuan, membentuk dan merubah sikap serta membuka kran untuk perubahan tingkah laku. Hanafi (1986) menyatakan bahwa media masa memiliki pengaruh besar terhadap seseorang jika orang tersebut menjadi anggota dalam forum media, pengaruh tersebut diantaranya:

1. Adanya minat untuk menghadiri dan berpartisipasi didorong oleh adanya tekanan dan harapan masyarakat, setidaknya kelompok forum itu sendiri. Ia tidak disenangi teman-temannya jika kurang rajin, sebaliknya ia akan mendapat pujian jika besar partisipasinya dalam kegiatan kelompok;

2. Perubahan sikap nampaknya lebih mungkin terjadi jika seseorang berada dalam kelompok. Dan lagi, keputusan kelompok akan lebih mungkin diterima seseorang jika ia ikut sera dalam pembuatan keputusan. Dalam bertemunya dalam kelompok dan pembahasan topik (inovasi) itu dengan teman-temannya, memungkinkan seseorang lebih cepat terbentuk sikapnya terhadap inovasi yang disampaikan melalui media massa;

3. Mungkin pula besarnya pengaruh forum media karena masih baru dan kredibilitasnya tinggi.

Berdasarkan observasi pada informan penelitian, minat terhadap sesuatu pada diri informan sangat dipengaruhi oleh teman, baik teman disekolah maupun teman bermain. Hal ini terlihat dari forum yang diikuti oleh informan, komentar-komentar serta dari postinganpostingan dari informan. Pengaruh nilai, norma dan keyakinan pada penyebaran informasi oleh remaja terlihat pada pola berikut:

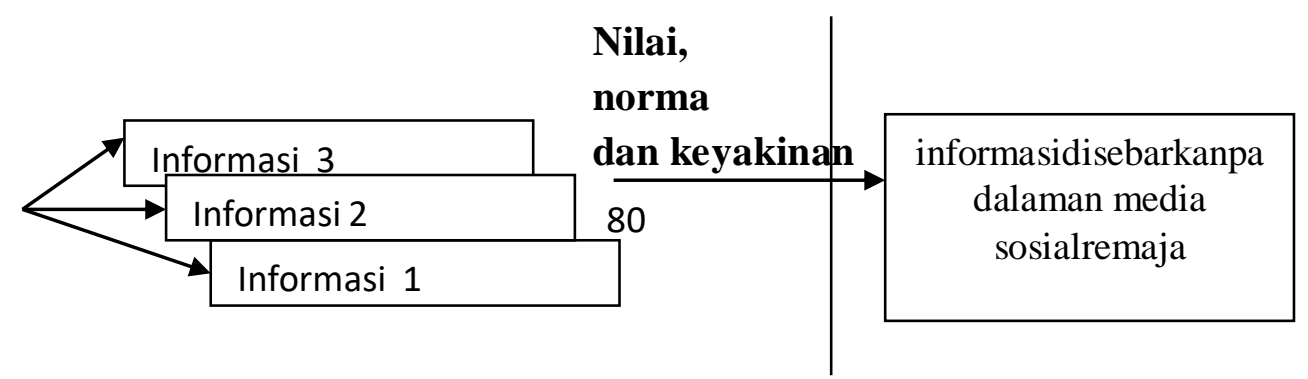




\section{Remaja}

Gambar 1.1 Pola penyebaran informasi remaja di media sosial

Selanjutnya terbentuk pola penyebaran informasi oleh remaja di media sosial, dimana remaja mengakses media sosial yang ia miliki kemudian dari laman yang mereka miliki mereka membaca berita/ artikel yang kemudian terdapat link pada artikel/ berita yang ada dan memungkinkan mereka menyebarkan informasi. Pada saat sebelum menyebarkan informasi remaja memiliki kesadaran akan nilai, norma dan keyakinan yang melatarbelakangi mereka untuk tidak serta merta menyeberkan berita/ artikel yang mereka baca. Berita-berita yang masuk dengan sendirinya dalam laman pribadi mereka tidak semua dibaca dan disebarkan oleh remaja. Informasi yang dianggap penting bagi anggota kominitas yang diikuti oleh remaja akan langsung disebarkan. Informan juga menunjukkan keberpihakan pada isu tertentu dengan menyebarkan informasi sesuai dengan pandangan mereka. Selain itu, informan juga membuat informasi baru dengan memberikan komentar pada informasi yang menarik dan dianggap penting. Informan juga kadang membuat status (menulis kolomm status) setelah melihat atau membaca suatu informasi di media sosial.

Hal ini senada dengan apa yang disampaikan oleh Albrechtslund (2010) dikatakan bahwa di media sosial persahabatan sejati bertahan selamanya, namun, dalam kasus jaringan sosial online, sentimen ini mendapat arti yang sama sekali berbeda. Jejak digital pertemanan online - benar atau tidak - benar-benar bertahan selamanya, karena disimpan tanpa batas waktu di server. Selain itu, dokumentasi persahabatan menjadi mudah diakses karena sifat informasi digital dan portabel. Dengan demikian, dunia maya mengubah hubungan sosial dan praktik tentang temporalitas, organisasi dan penonton. Boyd (2007) dalam Albrechtslund (2010) telah menyarankan bahwa media sosial online sebagai publik yang dimediasi ditandai oleh empat sifat: persistensi, kemampuan pencarian, peniru dan penonton tak terlihat. Media sosial online adalah bertahan lama, karena komunikasi disimpan tanpa batas waktu. Konsekuensi dari hal ini adalah, tentu saja, bahwa hal-hal yang orang tulis di blog mereka, posting komentar dan komunikasi instan dan situasi lainnya yang tampaknya instan akan tersedia dan dapat dilihat dengan mudah. Sifat yang kedua, mudah ditemukan kembali, hal ini membuat informasi tersedia di media sosial dengan mudah ditemukan dari beberapa kata kunci dan frase. Ketiga, sifat media sosial online adalah mudah untuk ditiru. Seperti informasi digital lainnya, informasi di media sosial dapat terlepas dari media spesifiknya dan 
diproduksi ulang dengan sempurna, bahkan diubah, dan dimasukkan ke dalam konteks lain. Poin terakhir menurut Boyd adalah penonton media sosial online yang tak terlihat. Meskipun orang secara jelas berkomunikasi secara online dengan pemirsa tertentu, misalnya, teman mereka, sifat publik media sosial yang online membuat informasi tersedia dapat dilihat oleh khalayak yang jauh lebih besar, yang berpotensi untuk setiap orang yang memiliki akses ke internet.

\section{PENUTUP}

\section{Simpulan}

Budaya pada dasarnya merupakan nilai-nilai yang muncul dari proses interaksi antar individu. Nilai-nilai diakui baik secara langsung maupun tidak langsung, seiring dengan adanya interaksi antar individu. Budaya merupakan nilai-nilai yang muncul akibat interaksi antar manusia, pada remaja interaksi melalui media sosial dengan menghasilkan informasi baru, baik yang diciptakan sendiri, dengan menambahkan informasi yang sudah ada, memberikan komentar bahkan menambahkan informasi dengan format lain. Terdapat nilai, norma dan keyakinan yang memberikan landasan pada segala tindakan yang dilakukan di media sosial. Media sosial dengan karakteristiknya memiliki dampak bagi remaja. Interaksi diantara remaja bisa berupa online atau offline membentuk budaya baru yang dipengaruhi oleh nilai, norma dan keyakinan. Hal ini karena di media sosial kita dapat mengetahui aktivitas orang lain melalui media sosial, sementara kita tidak kenal dan tidak pernah bertemu dan bertata muka dengan orang tersebut. Pola penyebaran informasi oleh remaja dilakukan melalui media sosial dilakukan setiap saat, dengan jenis informasi berkaitan dengan hobi, aktivitas sekolah dan kesenangan atau hiburan. Peran orang terdekat (orang tua, peer) sangat mempengaruhi remaja dalam menentukan informasi mana yang dapat disebarkan dan informasi mana yang tidak boleh disebarkan. Nilai saling menghormati sesama masih dimiliki oleh remaja dalam menyebarkan informasi.

\section{Saran}

Saran dari penelitian ini, pentingnya remaja memiliki kedekatan dengan orang tua sebagai pembentuk karakter anak sehingga remaja dapat mengahargai nilai-nilai dalam bergaul menggunakan media sosial dan mengetahui sesuatu yang baik dan benar dari sumber yang dapat dipercayaSelain itu, remaja harus dibekali kemampuan literasi informasi (kemampuan menentukan, menilai, menggunakan, dan mengevaluasi informasi). 


\section{DAFTAR PUSTAKA}

Albrechtslund, Albert. 2010. Online Social Networking as Partisipatory Surveillance. Fist Monday, Volume 13, Number 3 - 3 March 2008.

http://firstmonday.org/article/view/2142/1949 (diakses 19 Februari 2018)

Creswell, John W. 2010. Research Design: pendekatan Metode Kualitatif, Kuantitatif, dan Campuran. Yogjakarta: Pustaka Pelajar.

Endraswara, Suwandi. 2012. Metodologi Penelitian Kebudayaan. Yogjakarta: Gajah Mada University Press.

Harmsworth, Sally and Sarah Turpin. 2000. Creating and Effective Dissemintation Strategy.

Addition by Alexandra Rees \&GodFrey Pell, Bridging in Gap: Innovation Project.

Hanafi, Abdullah,. 1986. Memasyarakatkan Ide-Ide Baru. Surabaya: Usaha Nasional.

Hatch, Mary Jo. 1997. Organization theory: modern, symbolic, and postmodern perspective. USA: Oxford University Press.

Laksono, Dwi Agung., Ratna Dwi Wulandari. 2011. Analisis Potensi Penyebaran Informasi

Kesehatan: Studi Kasus pada Forum Jejaring Peduli AIDS. Bulletin of Health System Research. Vol 14, no. 4 Okt 2011.

http://ejournal.litbang.depkes.go.id/index.php/hsr/article/view/1373 (diakses 7

Februari 2018)

Laksmi \& Kiki Fauziah. 2016. Budaya Informasi. Jakarta: ISIPII Press.

Laksmi, Tamara Adriani Susetyo- Salim dna Ari Imansyah. 2010. Manajemen Lembaga

Informasi: Teori dan Praktik. Depok: Departemen Ilmu Perpustakaan dan Informasi.

Nasrullah, Rulli, Dr. M.Si,. 2015. Media Sosial: Perspektif Komunikasi, Budaya, dan Sosioteknologi.Bandung: Simbiosa Rekatama Media.

Rubin, Richard E. 2016. Fondations Library and Information Science. Fourth Edition. Chicago: Neal-Schuman. 